\title{
遅発性尺骨神経麻瘏患者の予後
}

\begin{tabular}{cllll} 
長崎大学整形外科 & \multicolumn{2}{l}{ (主任 : 永井三郎教授) } \\
江 川 & 正 & 啮 谷 俊 隆 \\
小 串 隆 & 郎 岡 崎 & 威 \\
長崎市民病院整形外科 & & & & \\
吉 田 博 & 利 & &
\end{tabular}

\section{The Results of Transposition of Tardy Ulnar Palsy}

By

\author{
T. Egawa, T. Shibuya, T. Ogushi \& T. Okazaki \\ Department of Orthopedic Surgery, Nagasaki University, \\ School of Medicine
}

\section{H. Yoshida}

Nagasaki Municipal Hospital, Orthopedic Surgery

Both clinical and electromyographical studies were made in 8 cases in which anterior transposition of ulnar nerve had been performed.

Period for following up varied from seven months to two years and ten months after operation.

The following conclusion were obtained.

1) In seven of the eight cases there were cubitus valgus in more 20 degrees which was followed old fracture of the elbow.

2) The motor improvement was observated in five cases of seven cases, but sensory recovery was noted by three cases of eight. No cases regained normal sensation.

3) The patient in whom the neuroma was noted to be of firm consistence at operation.

4) In electromyographical observation, high amp. NMU voltage were found in most of the muscles examined.

5) In evoked electromyographical studies, there was in nearly all cases a decrease in $\mathrm{m}$. c. v., amplitude and increase in threshold.

尺骨神経は, 时関節部における解剖学的条件によつ て，諸々な損傷を受け易いととが考えられるが，なか でも，遅発性尺骨神経麻㾝は，1887 年，Dr. Panas によつて初めて肘関節の変形に伴なう, progressive nerve lesion として 4 例が発表されて以来, その発 症機序や治療法などについては, 今日迄, 多数の報告 が行われている.私共の教室及び関係病院に於て, 昭 和29年10月以降, 42 年12月迄に, 当神経麻㾴に対し, 手術的治療を行つたあのは 18 例, 20 神経で, 今回, その予後調査を行い, 直接検診し得た 8 例 8 神経につ いて, その治療成績を臨床的, 且つ, 筋電図学上より 観察し得たので報告する.

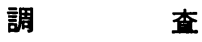

私共の教室開講以来, 本年 4 月迄に, 遅発性尺骨神 経麻神患者は, 34例で, これは, 同期間内における上 肢末梢神経麻㾝患者 359 名の $9.5 \%$ 亿当り, 決して少 ない疾患之は云えない. 34例について，その原因疾患 及び左右，性別との関係をみると，Cubitus valgus によるものが断然多く，26例を占め, 右側は, 左側に 比べ約 2 倍の䍜患率を示し, 且つ, 男性に多いととが 分る. Osteoarthritis によるものは6例で，全て男 性, 且つ, 肉体労㗢者であり, しかあ両側性に発生し ているあのああつて, 職業的関係の哚いことを示して 
表 1 患者 成績 一 覧 表

\begin{tabular}{|c|c|c|c|c|c|c|c|c|c|c|c|c|c|c|}
\hline & 氏名 & 患側 & 性 & \begin{tabular}{|c|} 
手術 \\
時 \\
年令
\end{tabular} & 因 & $\begin{array}{ll}\text { 術 } & \text { 後 } \\
\text { 経 } & \text { 過 } \\
\text { 年 } & \text { 数 } \\
\end{array}$ & $\begin{array}{l}\text { 筋 } \\
\text { 萎縮 }\end{array}$ & \begin{tabular}{|l|} 
発汗 \\
三人一 \\
ル反応
\end{tabular} & $\begin{array}{l}\text { 知覚 } \\
\text { 障害 }\end{array}$ & $\begin{array}{c}\text { 指変 } \\
\text { 形 }\end{array}$ & $\begin{array}{c}\text { Froment } \\
\text { sign }\end{array}$ & 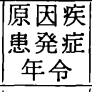 & $\begin{array}{l}\text { 症状発 } \\
\text { 現一手 } \\
\text { 術期間 }\end{array}$ & $\begin{array}{l}\text { 自覚的 } \\
\text { 改 善 }\end{array}$ \\
\hline 1 & & $\mathbf{R}$ & $\hat{\delta}$ & 27 & $\begin{array}{c}\text { Cubitus } \\
\text { valgus } 15^{\circ}\end{array}$ & $\begin{array}{l}1 \text { 年 } \\
9 \text { 力月 }\end{array}$ & $(-)$ & 正常 & 軽度 & $(-)$ & $(-)$ & 14才 & 8 力月 & $\stackrel{\mathrm{M}}{\mathrm{S}}$ 著明 \\
\hline 2 & & $\mathbf{R}$ & $\hat{\delta}$ & 51 & $\begin{array}{l}\text { Osteo- } \\
\text { arthritis }\end{array}$ & $\begin{array}{l}1 \text { 年 } \\
5 \text { 力月 }\end{array}$ & 軽度 & " & " & $(-)$ & $(-)$ & 不明 & 8 力月 & $M$ 著明 \\
\hline 3 & & $\mathbf{R}$ & $\hat{0}$ & 49 & $\begin{array}{c}\text { Cubitus } \\
\text { valgus } 20^{\circ}\end{array}$ & 1 年 & $\begin{array}{c}\text { 中等 } \\
\text { 度 }\end{array}$ & $\begin{array}{l}\text { 出現 } \\
(+)\end{array}$ & " & $(+)$ & $(+)$ & $6 才$ & 4 年 & $\mathrm{M}$ 軽度 \\
\hline 4 & & L & ๙ & 56 & " $35^{\circ}$ & $\begin{array}{c}2 \text { 年 } \\
10 \text { 力 }\end{array}$ & 軽度 & 正常 & " & $(-)$ & $(-)$ & 33才 & $\begin{array}{l}1 \text { 年 } \\
3 \text { 力月 }\end{array}$ & $\underset{\mathrm{S}}{\mathrm{M}}$ 著明 \\
\hline 5 & & L & $\hat{\delta}$ & 54 & " $20^{\circ}$ & $\begin{array}{l}2 \text { 年 } \\
8 \text { 力月 }\end{array}$ & $\begin{array}{c}\text { 中等 } \\
\text { 度 }\end{array}$ & $\begin{array}{l}\text { 出現 } \\
(+)\end{array}$ & $\begin{array}{c}\text { 中等 } \\
\text { 度 }\end{array}$ & $(t)$ & $(+)$ & $\begin{array}{l}2 \sim \\
3 才 ?\end{array}$ & 3 年 & $\mathrm{M}$ 軽度 \\
\hline 6 & & $\mathbf{R}$ & 우 & 38 & $" 17^{\circ}$ & $\begin{array}{l}2 \text { 年 } \\
2 \text { 力月 }\end{array}$ & 軽度 & $" \prime$ & 軽度 & $(-)$ & $( \pm)$ & $\begin{array}{l}\text { 小児 } \\
\text { 期 }\end{array}$ & 2 年 & $S$ 軽度 \\
\hline 7 & & $\mathbf{R}$ & 今 & 21 & $\begin{array}{l}\text { 尺側上果 } \\
\text { 骨 折 }\end{array}$ & 1 年 & $(-)$ & 正常 & " & $(-)$ & $(-)$ & " & 2 力月 & $( \pm)$ \\
\hline 8 & & L & $\hat{\delta}$ & 17 & $\begin{array}{l}\text { Cubitus } \\
\text { valgus } 20^{\circ}\end{array}$ & 7 力月 & 軽度 & $\begin{array}{l}\text { 出現 } \\
(+)\end{array}$ & " & $(-)$ & $( \pm)$ & 3 才 & 1 年 & $(-)$ \\
\hline
\end{tabular}

\section{$M$ : 筋萎䑿 $\mathrm{S}$ : 知覚}

いる. 又, 年令では, 20 才台と 40,50 才台に多くな つており，中であ，Cubitus valgus に起因するむの は, 40才迄に発症するあのが多く, Osteoarthritis に よるものは, 壮年期以後, 特に, 50才台に多く認めら れているが，乙の相違は，原疾患の発症時期に因をな すむのと考えられる.

次に，18例の手術々式の内容についてみると，肘関 節前方皮下移行術を行つたものが, 14 例，16 神経で 最屯多く，他に，Keil-Osteotomie 2 例，前方移行術 十尺側上果骨切り術を併用したものが 2 例である.

\section{症例}

今回の調査で, 実際に検診し得た患者は男性 7 例, 女性 1 例で，原因疾患別では, 8 例中 6 例が, Cubitus valgus の変形に起因し, 他の 2 例は, 夫々, Osteoarthritis と尺側上果骨折後の 変形により続発したも のであつて, 術式は, 全て, 前方皮下移行術を行つた あのである.

術後経過年数 : 最短 7 ケ月より最長 2 年 10 ケ月迄 で, 8 例中 7 例は, 術後 1 年以上を経過したものであ る(表 1 ).

Cubitus valgus の程度 : 20 度以上の変形をもつも のが大多数を占め, かかる神経障害発生予知の一指標
になると考えられる.

筋萎縮 : 術前より 明らかに存在するすのが 7 例あ り, この中, 今回の調查時に, 萎縮の略消失したもの は唯一例のみで, 筋萎縮の完全回復の困難さを物語つ ている. 特に, 症状発現より手術迄の期間が, 3 年以 上に及ぶ者では, 筋萎縮の回復状況は極めて悪く，未 だ Claw hand deformity を呈しており，筋力テスト でも，明らかな低下を認める。

知覚障害 : 全例共, full recovery を示したものは なく, 筋萎縮の著明な症例に於てさえも, 軽度ながら 知覚異常を残しており，McGowanなどの述べる程， 知覚回復が良好なむのばかりとは云い難いように思わ れる. 特に手術迄の期間が長期にわたる症例では, 筋 萎縮の回復に比べ, 知覚の改善は悪く, このととは, Sulcus nervi ulnaris 部位における尺骨神経内の motor, sensory nerve fibre の位置的関係が, 大い に関与してくるものと考える.

術後経過年数亡筋萎縮及び知覚回復の関係 : 表でも みられる如く, 知覚の改善に比へ, 筋萎縮の回復を認 めるあのが多く, 殊に, 一年以上経過した症例では, 程度の差はあるが, 全ての症例に認めている.乙れに 反し, 知覚の改善度は可成り劣つている.

手術所見と治療成績：8例中 3 例に Neurom 形成 
表 2 Evoked E. M. G. 成 績 表

\begin{tabular}{|c|c|c|c|c|c|c|c|c|}
\hline \multirow{2}{*}{ 氏 名 } & \multirow{2}{*}{$\begin{array}{l}\text { 左右 } \\
\text { 別 }\end{array}$} & \multirow{2}{*}{$\begin{array}{l}\text { M. C. V. } \\
\text { (m/sec.) }\end{array}$} & \multirow{2}{*}{$\underset{(\mathrm{mv})}{\text { Amplitude }}$} & \multicolumn{2}{|c|}{$\begin{array}{c}\text { Threshold } \\
\text { (V) }\end{array}$} & \multirow{2}{*}{$\begin{array}{l}\text { M. C. V. } \\
\text { (m/sec.) }\end{array}$} & \multirow{2}{*}{$\underset{(\mu \mathrm{v})}{\text { Amplitude }}$} & \multirow{2}{*}{$\begin{array}{l}\text { 自覚的 } \\
\text { 敏 善 }\end{array}$} \\
\hline & & & & $\min$ & $\max$ & & & \\
\hline & $\left(\begin{array}{l}\mathrm{L} \\
\mathrm{R}\end{array}\right)$ & $\begin{array}{l}46.5 \\
35.0\end{array}$ & $\begin{array}{l}9.5 \\
7.7\end{array}$ & $\begin{array}{l}16 \\
17\end{array}$ & $\begin{array}{l}28 \\
35\end{array}$ & $\begin{array}{l}71.4 \\
71.4\end{array}$ & $\begin{array}{l}18 \\
18\end{array}$ & $\begin{array}{l}M(H) \\
S(H)\end{array}$ \\
\hline & $(\mathrm{L})$ & $\begin{array}{l}60.0 \\
50.0\end{array}$ & $\begin{array}{l}4.8 \\
1.1\end{array}$ & $\begin{array}{l}15 \\
16\end{array}$ & $\begin{array}{l}54 \\
60\end{array}$ & & $\stackrel{18}{(-)}$ & $M(H)$ \\
\hline & $(\stackrel{\mathrm{L}}{\mathrm{R}})$ & $\begin{array}{l}72.3 \\
36.1\end{array}$ & $\begin{array}{l}0.9 \\
0.54\end{array}$ & $\begin{array}{l}22 \\
38\end{array}$ & $\begin{array}{l}47 \\
60\end{array}$ & & $(-)$ & $\mathbf{M}(+)$ \\
\hline & $\underset{\mathrm{R}}{(\mathrm{L})}$ & $\begin{array}{l}25.0 \\
45.5\end{array}$ & $\begin{array}{l}1 \\
3\end{array}$ & $\begin{array}{l}25 \\
19\end{array}$ & $\begin{array}{l}56 \\
46\end{array}$ & 55.4 & $\left(\frac{-}{20}\right)$ & $\begin{array}{l}\mathrm{M} \\
\mathrm{S}\end{array}(+\mathrm{H})$ \\
\hline & $(\underset{R}{L})$ & $\begin{array}{l}25.0 \\
45.5\end{array}$ & $\begin{array}{l}0.36 \\
3.9\end{array}$ & $\begin{array}{l}30 \\
15\end{array}$ & $\begin{array}{l}60 \\
35\end{array}$ & & $\left(-\frac{-}{20}\right)$ & $\mathrm{M}(+)$ \\
\hline & $(\stackrel{L}{R})$ & $\begin{array}{l}52.0 \\
43.4\end{array}$ & $\begin{array}{l}9.4 \\
3.6\end{array}$ & $\begin{array}{l}16 \\
16\end{array}$ & $\begin{array}{l}36 \\
54\end{array}$ & & $\stackrel{18}{-})$ & $s(t)$ \\
\hline & $(\stackrel{L}{R})$ & $\begin{array}{l}51.3 \\
50.2\end{array}$ & $\begin{array}{r}10.4 \\
8.6\end{array}$ & $\begin{array}{l}18 \\
19\end{array}$ & $\begin{array}{l}40 \\
45\end{array}$ & $\begin{array}{l}55.6 \\
45.5\end{array}$ & $\begin{array}{l}25 \\
17\end{array}$ & $S( \pm)$ \\
\hline & $(\underset{R}{L})$ & $\begin{array}{l}46.6 \\
63.8\end{array}$ & $\begin{array}{l}1.57 \\
8.25\end{array}$ & $\begin{array}{l}25 \\
10\end{array}$ & $\begin{array}{l}48 \\
39\end{array}$ & & $(-)$ & $(-)$ \\
\hline
\end{tabular}

$\mathrm{M}$ : 筋萎縮 $\mathrm{S}$ : 知覚 （）：患側

を認め, うち， 2 例は, 症状発現 から 3 年以上を経 過した Cubitus valgus の症例であり，他の 1 例は， 症状発現より 8 ケ月で Neuroma 形成を認めた Osteoarthritis の症例である. かかる Neuroma 形成の症 例では, それのない症例に比べ, 筋萎縮, 知覚共に, その回復は悪いが, 症例によつては筋萎縮の面で臨床 的, 筋電図学的にも相当な回復が認められるものがあ り, 遅発性尺骨神経麻㾝が, 他の外傷性神経損傷と異 なる点と考える.

筋電図学的所見 : Fibrillation voltage などの安静 時放電を認めた例はなく, voluntary で, 大部分のも のに High Amp. NMU voltage や Polyphasic Potential などの異常波形を認め, 正常波形を認める 者は少なく, reinnervation 途上の状態にあるととを 示している.

誘発筋電図学的所見 : (表 2) 筋萎縮が著明に回復 した例です，健側に比べ, Motor conduction velocity (以後 M.C.V. と略す) や Amplitude の低下, 闇值 の上昇が目立.ち, larger fibre の再生や reinnervation の不充分なととを示しており，更に， Sensory nerve action potential を認め得たものは 2 例に過ぎず, 臨 床的知覚改善の拙劣さを裏づけている.

又, Strength-Duration Curve についてみると,
M.C. V. よりみた成績より，やや良好な結果を示し， 筋萎縮が著明に回復した例では, 健側と大差ないグラ フを呈するが, 回復の悪い症例では, Adrian の述べ ている Curve の discontinuity の出現や閔値の上昇 を認める.

更に, 刺戟の Duration を $0.1 \mathrm{~ms}$ より漸次増大し つつ, 夫ヶの latency (Elbow より M. abd. dig. quint 迄）及び最大振巾值を测定してみると，正常者 では, 両者共, 弱い刺戟時に軽度の変動を認めるが, 刺戟の増大と共に, 略直線状を示すのに対し, 回復の 悪い症例では, latency の変動は少ないが,刺戟の増大 によつても，著明な延長を示したままであり，最大振 巾值についても, 最初やや振巾の増大を認めるが, 以 後, 増大の傾向を示さず, 正常例に比べ極めて低い振 巾値を示す. これに対し，筋萎縮の著明でない例で は, 弱い刺戟で latency が健側に比べ,やや延長を示 すが, 刺戟の増大と共に, 略, 健側に近い值を示すよ うになり, 又, 最大振巾值では, 刺戟の増大に伴なつ て著しい振巾の変動を認める. このととは回復途上に ある axon の成熟度と, muscle fibre への reinnervation の程度を如実に 示しているすのと考えられよ う. (図 1 )

発汗テスト：このテストで, 全く発汗を認め得なか 
证 7

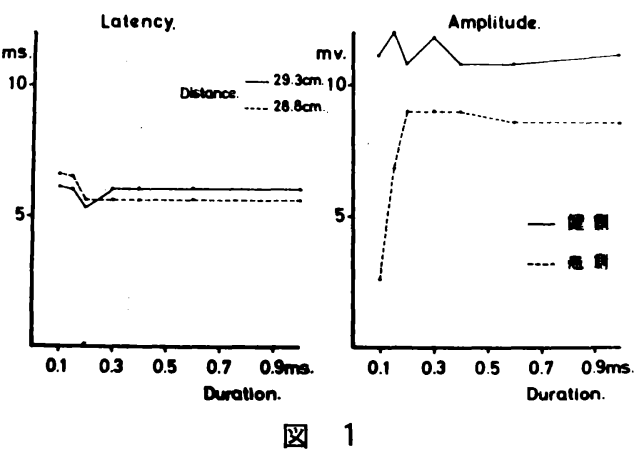

つた者は，1例むなかつたが, 中等度の筋萎縮を有する 2 例之筋萎縮, 知覚共に改善の見られない 1 症例で, 尺骨神経領域に発汗の減少が認められた。

総合成績: 以上, 8 例の治療成績を筋萎縮と知覚改 善の面より判定すると，筋萎縮を有していた 7 例中, 著しい改善を認めるあの 2 例, 軽度改善が認められる もの 3 例, 不変のむの 2 例, 知覚障害を有していた 8 例中, 著しい改善を認めるもの 2 例, 軽度改善が認め られるもの 1 例, 不変のもの 5 例で, 両者共, 改善が 認められないものは 1 名である，又，両者共，著明な 改善を認めたものは 2 名で，乙れらは，手術所見上， Neuroma 形成はなく，しかも，術後経過年数が夫 々， 1 年 9 ケ月及び 2 年 10 ケ月のあのである. しか し, 一般筋電図, 誘発筋電図や筋力テストなどの諸検 查で, 略, 正常に近い回復を示すあのは 1 例に過ぎ ない.

\section{総括}

tardy ulnar palsy の原因としては，従来より肘関 節部骨折後の変形に起因するものが大部分で, 中でも 上腕骨撓側果骨折後の変形に伴なう, Cubitus valgus が最む多いとされており，今回の調查であ， 8 例中 6 例に認められ，时関節部骨折の治療に当つては, この 点を充分考慮する必要のあることを痛感させられるあ のである.

本症の発生機序として, Osborne の Compression lesion を初めとして, 粗造な groove の friction に むとづくあのや, nerve trunk の stretching, repeated mild trauma などが原因として述べらている が，私共の手術所見からみても， case by case で， いろいろな異なつた所見を呈するとてろから，Kallio
む述べている如く，夫々の機転が互に交錯し，かかる 症状を呈してくるものと考える.

蓮江氏らによると，重症例です，1 年以上の観察で 過半数に 良好な回復を認めるとし，McGowan は， Grade I の軽症例では, full recovery を得るが。 Grade II の中等度障害例では, motor 及び sensory の回復が不充分なものが生じ, Grade III の重症例に 於ては, motor function の完全回復は稀であるが, sensory の回復は略, 満足すべきあのであるとして いる.

しかるに, 私共の症例に於ては, その変性程度の相 異はあるにしても, 筋萎縮の改善度に比べ, sensory は必ずしも満足すべき症例ばかりとは云い難いように 思われる. このととは, 個々の症例に於て, intraneural の変化の及ぶ範囲が夫々異なり, それが, 尺骨 神経の Topograph の位置的条件との相互関係によつ て，かかる相違が生じるすのと考えられる。

又, 誘発刺戟の変化に伴なう latency 及び amplitude の推移は, 再生途上にある axon の成熟度と muscle fibre への reinnervation の程度を良く示し 予後判定に有効な指標之思われる.

Brooks は, かかる神経の回復は, 損僨部位がもつ 可逆性変化と, motor, sensory の endorgan 及び muscles における可逆性変化の二つの要素によつて定 まるとしており, 従つて, 8 ケ月以上にわたる denervated muscles をもつ症例では，筋に二次的変化が 生じ, function の回復は不可能であるとしているが, 発症後, 8 ケ月で Neuroma の形成を認めた症例で あ, 術後回復の良好なあのもあり, 必ずしも悲観的と は考えられない. かかる観点より, 本疾患の場合は, 積極的な治療が望ましいと考える.

結語

1）本麻疸患者は，上肢末梢神経損傷患者の $9.5 \%$ 程度にみられる。

2）原因疾患は, Cubitus valgus deformity によ るすのが大多数であり, しかも 20 度以上の変形をあ つものが多い.

3）術後一年以上のあのでは, 筋萎縮の回復が認め られるものが多くなるが, 反面, 知覚改善は, 従来, 報告されていたものより劣るように思われる。

4）筋電図上では, 大部分のむのに High Amp. NMU Voltage を認める. 
5) 誘発筋電図上では, M. C. V., Amplitude の 低下, 闧值の上昇を示すすのが多く, sensory nerve action potential を認め得たものは 2 例にすぎない.

（御協力を頂いた, 長崎原爆病院, 長㥓市民病院整 形外科各位及び御指導頂いた，永井教授に深謝致しま す.)

\section{文献}

1) 木村正己 - 他 : 中部日本整形災害外科学会誌. $8: 95$, 昭 40 .

2) A. J. McGowan : J. B. J. S., 32-B : 291, 1950.

3) Childress : J. S. J. S., 38-A : 979, 1956.

4) Brooks : J. B. J. S., 32-B : 291, 1950.

5) Osborne : J. B. J. S., 39-B : 782, 1957.

6) 蓮江光男 - 他 : 整形外科. $14: 902,1964$.

7) Kallio : Acta orth. Scand. $33: 227,1963$,

8) Robert Hodes \&W. German : Arch. Neurol. and Psych. $60: 340,1940$.

9) L. J. Pollock : Surg. Gyn. and Obstet. 79 : 133, 1944.

10) R. W. Gilliatt : J. Neurol. Neurosurg. and Psychiat. $23: 312,1960$.

11) 上平用: 災害医学. $8: 475,1965$.

12）高岸直人・他: 整形外科と災害外科. $10: 165$, 昭32.

追加及ひ啠問鳥取大 上平 用

遅発性尺骨神経麻㾇 23 例について, 神経伝導速度
を測定し，速度の程度と諸種外科的療法の治療成績と の関係を調査した.

質問；遅発性尺骨神経麻疸は連続性を保つているに かかわらず予後が悪い. 発症から手術までの期間, 解 剖的特殊性などいろいろ之原因はあろうが, 予後の不 良の真の原因は何か.

\section{回答}

遅発性尺骨神経麻㾝と外傷性神経損傷の回復に及ほ す相違の原因について，私自身明確な見解をもた ない。

\section{啠間鳥取大浜崎条男}

1. Cubitus valgus の程度と Spätlähmung との 関係は?

2. 手術の選択について

回答演者

1. Cubitus valgus の程度と麻疸の程度について症 例が少ないので見解を述べることが出係ないが, 今回 の症例からみた限りでは, $20^{\circ}$ 以上の変形を持つあの が大部分なので, ての点将来の麻㾝に対し注意する必 要があると考える.

2. 手術法の選択については, 各病院で行われた症 例なので一定の規準にあとずいた選択を行うことは出 来なかつた。 